Int. J. Dev. Biol. 53: 1035-1044 (2009)

doi: $10.1387 / \mathrm{ijdb} .072470 \mathrm{fc}$

\title{
The spatio-temporal pattern of testis organogenesis in mammals - insights from the mole
}

\author{
FRANCISCO D. CARMONA\#, DARÍO G. LUPIÁÑEZ, JOSÉ-EZEQUIEL MARTÍN, MIGUEL BURGOS, \\ RAFAEL JIMÉNEZ* and FEDERICO ZURITA \\ Departamento de Genética, Universidad de Granada, Granada, Spain
}

\begin{abstract}
Some cellular events are crucial in testis organogenesis, including Sertoli and Leydig cell differentiation, mesonephric cell migration and testis cord formation. These processes are controlled by transcription factors, paracrine signalling and hormones. Using the mole species Talpa occidentalis as an alternative animal model, we report the expression patterns of nine genes during testis differentiation and analyse their implications in the above-mentioned cellular processes. We show that: 1) Sertoli cell differentiation occurs very early and precedes mesonephric cell migration, indicating that the latter is not needed for the endocrine cytodifferentiation of Sertoli cells; 2 ) the time of Leydig cell differentiation is consistent with the participation of PDGFR- $\alpha$ in promoting the migration and/or proliferation of Leydig cell precursors, and with that of WNT4 signalling in inhibiting Leydig cell differentiation and 3) the formation of the tunica albuginea involves intragonadal cell migration/movement. These results demonstrate that testicular organogenesis in the mole differs from that in the mouse in some particular aspects, thus providing evidence that the spatio-temporal pattern of testis development is not highly conserved during mammalian evolution.
\end{abstract}

KEY WORDS: Sex determination, gonad, Sertoli cell, Leydig cell, cell migration, SOX9, AMH, Talpa

\section{Introduction}

Mammalian sex differentiation takes place in two steps. In the first, the undifferentiated gonadal primordia, which are present in both males and females, develop either as testes, or as ovaries. In marsupials and placental mammals, this process depends on the presence of the $Y$-linked gene $S R Y$ (sex-determining region of the Y chromosome; Sinclair et al., 1990). SRY encodes a putative transcription factor which acts as the genetic switch for male development by triggering a gene cascade where the genes of the male pathway (SF1, SOX9, FGF9, DMRT1, DAX1, AMH) are upregulated, whereas those of the female pathway (WNT4, FST) are downregulated (see Ross and Capel, 2005, for a review). Expression of $S R Y$ at the time of sex determination results in the formation of testes in males (XY). Its absence in females $(X X)$ results in ovarian differentiation at some point later on in development. In the second step, once the gonads are differentiated as testes, the androgens produced by the testis directs the differentiation of the urogenital tract of the male embryo, thus resulting in the formation of the male secondary sex features, including external genitalia. In the absence of testicular androgens, a female phenotype develops (Jost, 1947).

The genitourinary system of mammals derives from the intermediate mesoderm. In mice, gonadal primordia appear 10 days post coitum (dpc) as paired thickenings of the coelomic epithelium in the ventrolateral surface of each mesonephros, a structure functioning as a primitive kidney during embryogenesis. This thickening is referred to as genital ridge and is composed of

\footnotetext{
Abbreviations used in this paper: AMH, Anti-Müllerian Hormone; CRL, crowrump length; DMRT1, dsx- and mab3-related transcription factor 1; DPC, days post coitum; ELISA, Enzyme-Linked Immuno-Sorbent Assay; kD, Kilo Dalton; MT1-MMP, Matrix Type 1 Membrane Metalloproteinase; P450scc, P450 side chain cleavage; PBS, phosphate-buffered saline; PDGFR $\alpha$, Platelet Derived Growth Factor receptor $\alpha$; PGC, primordial germ cell; SF1, Steroidogenic Factor 1; SOX9, Sry-like HMG-Box protein 9; SRY, gene on the sex region of the Y chromosome; WNT4, wingless-related MMTV integration site family member 4 .
}

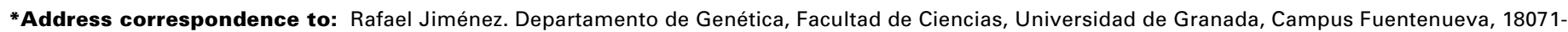
Granada, Spain. Fax: +34-95-824-4073. e-mail: rjimenez@ugr.es

\#Current address: Institute of Medical Sciences, Foresterhill, Aberdeen - AB25 2ZD, UK.

Accepted: 13 December 2007. Published online: 12 June 2009.

ISSN: Online 1696-3547, Print 0214-6282

(C) 2009 UBC Press

Printed in Spain 
somatic cells (mesothelial, mesenchymal and endothelial cells) and primordial germ cells (PGCs) coming from the extraembryonic mesoderm through the gut mesentery (McLaren, 2003). Once PGCs have colonized these undifferentiated gonads, there is a high proliferation of the somatic cells, mainly of the mesothelial and mesenchimal type. In this manner, the cells of the gonadal primordia become closely packed between the coelomic epithelium and the mesonephric mesenchyme.

In mammals, testes differentiate at an earlier stage than ovaries. Accordingly, it was hypothesised that the male pathway is an active process that anticipates ovarian fate in the undifferentiated gonad. In mice, although Sry expression can be detected by $10.5 \mathrm{dpc}$, the most important events of the testis development take place between 11.5 and $12.5 \mathrm{dpc}$, which is when the first morphological signs of gonadal sex differentiation appear. One of them is the colonization of the $X Y$ gonad by undifferentiated cells coming from the adjacent mesonephros (Martineau et al., 1997). This cell migration involves mainly endothelial cells, which organize the testicular vascular system (Brennan etal., 2002). It is also known that a few steroidogenic Leydig cell precursors do enter the gonad by migration from the mesonephros (Jeays-Ward et al., 2003). Peritubular myoid and perivascular cells are assumed also to take part in the migration process (Martineau et al., 1997), although this assumption has yet to be demonstrated via molecular markers. Mesonephric cell migration and a high proliferation of epithelial somatic cells take place simultaneously. These cells begin to differentiate as Sertoli cells, the main somatic cell type of the testis, which aggregate around PGCs forming testicular cords (Merchant-Larios and Taketo, 1991). It has been suggested that mesonephric cell migration is necessary for Sertoli cell differentiation and testicular cord formation (Tillman and Capel, 1999; see also Brennan and Capel, 2004 for a review).

As a result of Sertoli cell differentiation, some interstitial somatic cells differentiate as peritubular myoid cells, which surround testis cords and cooperate with Sertoli cells to deposit a basal lamina around them (Tung and Fritz, 1987). Other interstitial cells differentiate as either fibroblasts, endothelial cells, or Leydig cells (Merchant-Larios and Taketo, 1991). The masculinization of the mouse embryo body begins from $12.5 \mathrm{dpc}$ and is determined by three testicular hormones: Leydig cells produce testosterone and Insl3, which induce the differentiation of the Wolffian ducts within male reproductive tracts and the descent of testes, respectively (Nef and Parada, 1999), whereas Sertoli cells produce antiMüllerian hormone $(\mathrm{AMH}$; also referred to as Müllerian inhibiting substance, MIS) which promotes the regression of the Müllerian ducts, the precursors of the female reproductive organs (Vigier et al., 1987).

Some mole species of family Talpidae show exceptional reproductive features. Female moles represent the only case of generalized XX true hermaphroditism described so far in mammals, since all of them are fertile despite that they have bilateral ovotestes (gonads with both ovarian and testicular tissue) instead of normal ovaries (Jiménez et al., 1993; Sánchez et al., 1996, Rubenstein et al., 2003). Barrionuevo et al. (2004a) studied the gonad development in the Iberian mole, Talpa occidentalis, showing that the testicular portion of the ovotestes in XX moles develops in a testis-like pattern. Genital ridges are detectable at the s4 stage of mole development (corresponding to 14-16 dpc; Barrionuevo et al., 2004b; the entire gestation length in this species is 28 days), and testicular cords are first observed at the s5b stage (18 dpc) in both males and females. This study also showed that the development of the $X Y$ testicular tissue in males is morphologically similar to that found in other mammals. The vascular system of the testis and the first myoid and Leydig cells appear at stage s6 (19-21 dpc), and the tunica albuginea is formed between $\mathrm{s} 6$ and the last prenatal stage s8 (24-28 dpc).

In this paper, we report on the study of the expression of several genes currently known to be involved in mammalian sex determination and differentiation during crucial stages of testis development in males of the mole $T$. occidentalis. Our results show that, contrary to the situation described in mice, Sertoli cell differentiation is probably independent from mesonephric cell migration in moles, and occurs substantially before testis cords become histologically detectable. Testis-cord formation in the mole occurs much more slowly than in the mouse, allowing for a more precise establishment of the sequence of events accompanying this process, including Leydig cell differentiation and the formation of the tunica albuginea.

\section{Results}

Specificity of the anti-WNT4 antibody produced in this study

Most antibodies used in this study are commercially available, and their specificity has been investigated previously by the corresponding manufacturers. However, the WNT4 antibody produced in our laboratory needed to be tested for proper specificity

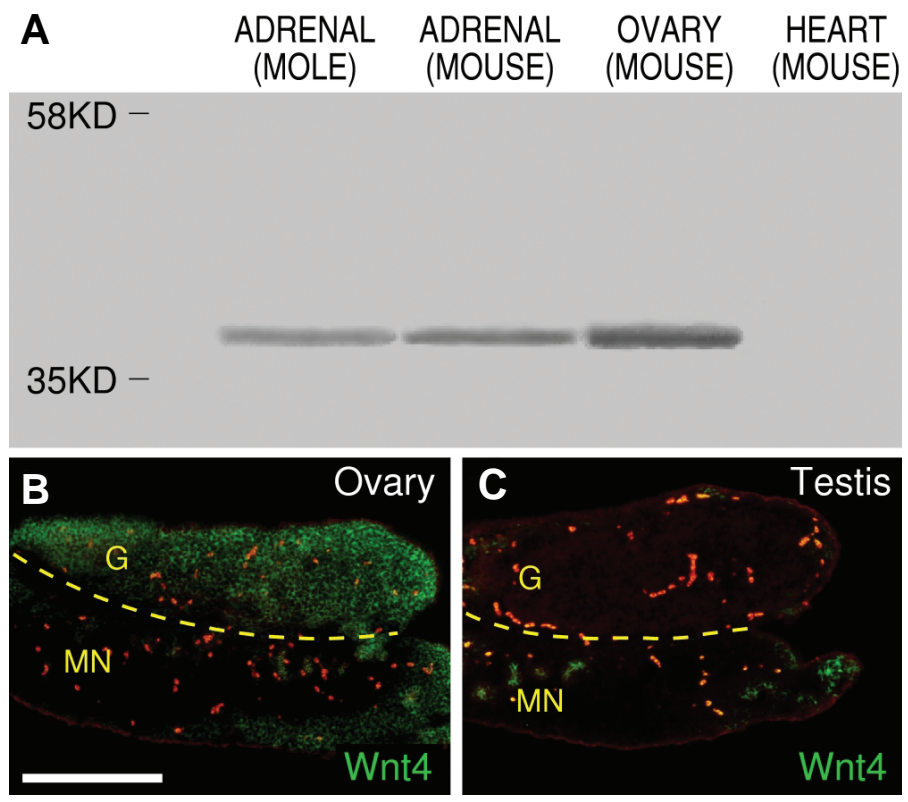

Fig. 1. Specificity of the mole anti-WNT4 antibody developed in this study. (A) Western blot analysis of WNT4 showing a $39 \mathrm{kD}$ band detectable in the samples of adrenal gland from both mouse and mole, and of mouse ovary. The negative control, mouse heart, did not provide any cross-reaction. (B,C) Immunostaining of mouse $12.5 \mathrm{dpc}$ gonads using the novel anti-WNT4 serum: mouse ovary shows high expression of Wnt4 (B), whereas mouse testis does not (C), as described for this species. G, gonad; $M$, mesonephros. The dotted line marks the gonadmesonephros border. Mole erythrocytes are autofluorescent, showing reddish fluorescence in both $(B, C)$. Scale bar represents $200 \mu \mathrm{m}$ in $(B, C)$. 
against the WNT4 protein. For this, western-blotting analyses and immunofluorescence were peformed on mouse gonads (Fig 1). The western blotting (Fig. 1A) identified a single band in samples of adrenal gland from both the mouse and the mole, as well as in mouse ovary (tissues where this gene is known to be expressed). However, no band was present in the mouse heart sample, which was used as negative control. This band was $\sim 39 \mathrm{kD}$ in size, the molecular weight reported for the WNT4 protein. Furthermore, the immunofluorescence technique showed that the mole WNT4 antibody detected abundant immunoreactive cells in the gonads of female but not in those of male mice (Fig. $2 \mathrm{~B}, \mathrm{C}$ ), this coinciding with the expression pattern known for this gene in this species. The 293bp fragment of the mole WNT4 gene that was amplified to produce this antibody (EMBL accession number: AM698098) was 91.3\% and $90.2 \%$ identical to those of the human and mouse genes, respectively, whereas the translated amino-acidic sequence was $100 \%$ identical to those of these two species.

\section{Correspondences between stages of gonad development in the mouse and the mole}

For comparisons of gonad-development patterns of mice and moles, the equivalences between developmental stages in both species needs to be established during the period in which the gonads emerge and differentiate. Two key events of testicular development, the appearance of the genital ridge and the formation of the testis cords, were taken as reference stages to establish the parallelism between these two species. As shown in Fig. 2, the formation of the genital ridge in the mole begins at the $s 4 b$ stage $(15 \mathrm{dpc})$, in the mouse at $10.5 \mathrm{dpc}$, whereas the testis cords appear at the s5b stage (18 dpc) and $12.5 \mathrm{dpc}$, respectively. Hence, the time elapsed between these two events was three days in the mole, and two days in the mouse. Only one day after the formation of the testis cords ( $55 \mathrm{c}$ moles and $13.5 \mathrm{dpc}$ mice), the testis appeared slightly more developed in the mouse than in the mole, and the difference was more evident after one more day. The mouse testis grew faster and became larger than the mole testis during the same developmental period. The mouse testis cords were clearly more conspicuous than those of the mole in these low-magnification images of fresh gonads.

\section{Very early expression of Sertoli cell markers in the mole testis}

The moment of Sertoli cell differentiation in male moles was studied by establishing the time-course expression of four Sertolian molecular markers: SF1, SOX9, AMHand DMRT1, as shown in Fig. 3. Most cells of the $s 4 \mathrm{~b} X Y$ gonad appear strongly immunoreactive against the SF1 antibody. At s5a, cells inside the developing cords showed stronger fluorescence than did those outside of them, but the opposite was true in s $5 b$ and later
MOLE
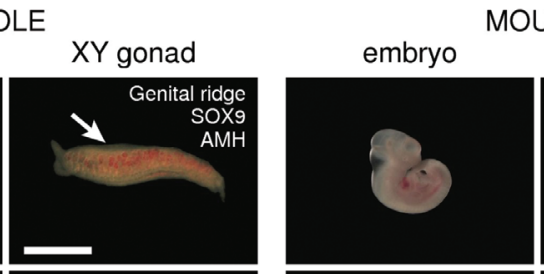

MOUSE
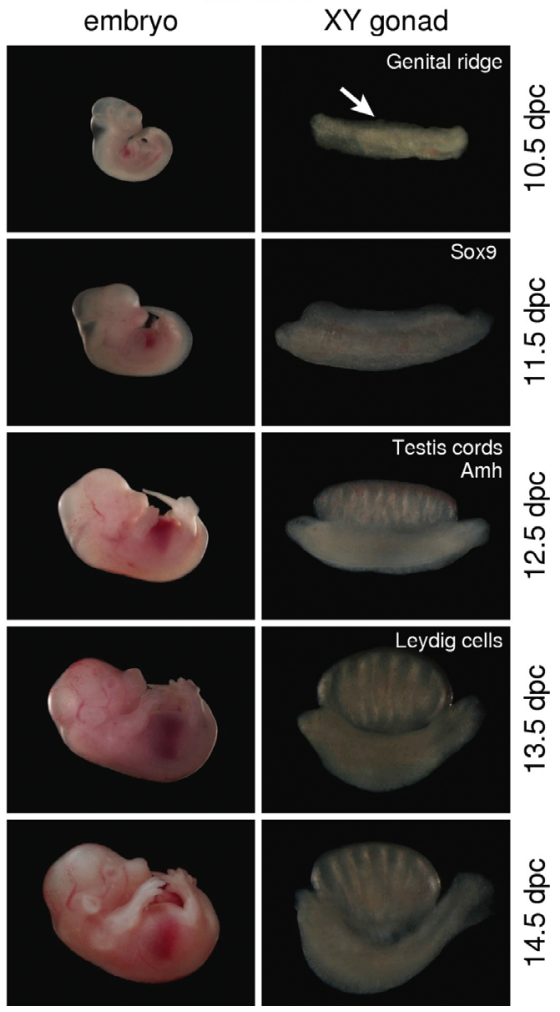

응

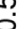
$\frac{0}{0}$

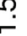
잉 mi

\section{$\frac{10}{8}$ is 묭}

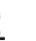

Fig. 2. Correspondences between developmental stages of the mouse and the mole during a five-day period around the time of sex differentiation. Images of the embryos and the gonad-mesonephros complexes are shown for each stage in both species. The dpc embryos, and the testis cords at $12.5 \mathrm{dpc}$; mouse testis cords are much more conspicuous than those of the mole testis at this point and at subsequent stages. The scale bars represent $5 \mathrm{~mm}$ in the embryo columns and $0.5 \mathrm{~mm}$ in the gonad columns.

stages (Fig 3, first row). SOX9 expression is evident in most cells of the medullary region of the gonadal primordium in $X Y$ gonads of the $s 4 b$ and $s 4 c$ stages (Fig. 3, second row), coinciding with the formation of the genital ridge. The expression persists later on in the developing testis cords, which are discernible for the first time in s5a gonads in SOX9immunostained sections, and become evident from s $5 \mathrm{~b}$ on. The expression pattern of the DMRT1 gene closely parallels that of $S O X 9$ (Fig.3, third row). The expression of $A M H$ in male moles (Fig. 3, fourth row) begins in a few cells located in the most central region of the gonad at stages as early as $s 4 b$; this expression is generalized to most cells of the developing testis cords two days later ( $55 a$ stage), and is maintained in cells inside the testis cords at $s 5 b$ and $s 5 c$ testes. WNT4 protein was first detected at the $s 4 b$ stage in the medullary region of $X Y$ gonads (Fig. 3, fifth row), but the expression was not as strong as in XX gonads (not shown). The expression decreases during the following stages ( $55 a$ and s5b), and is not detectable at s5c. The scarce protein that remains in $s 5 b$ testes permitted us to 


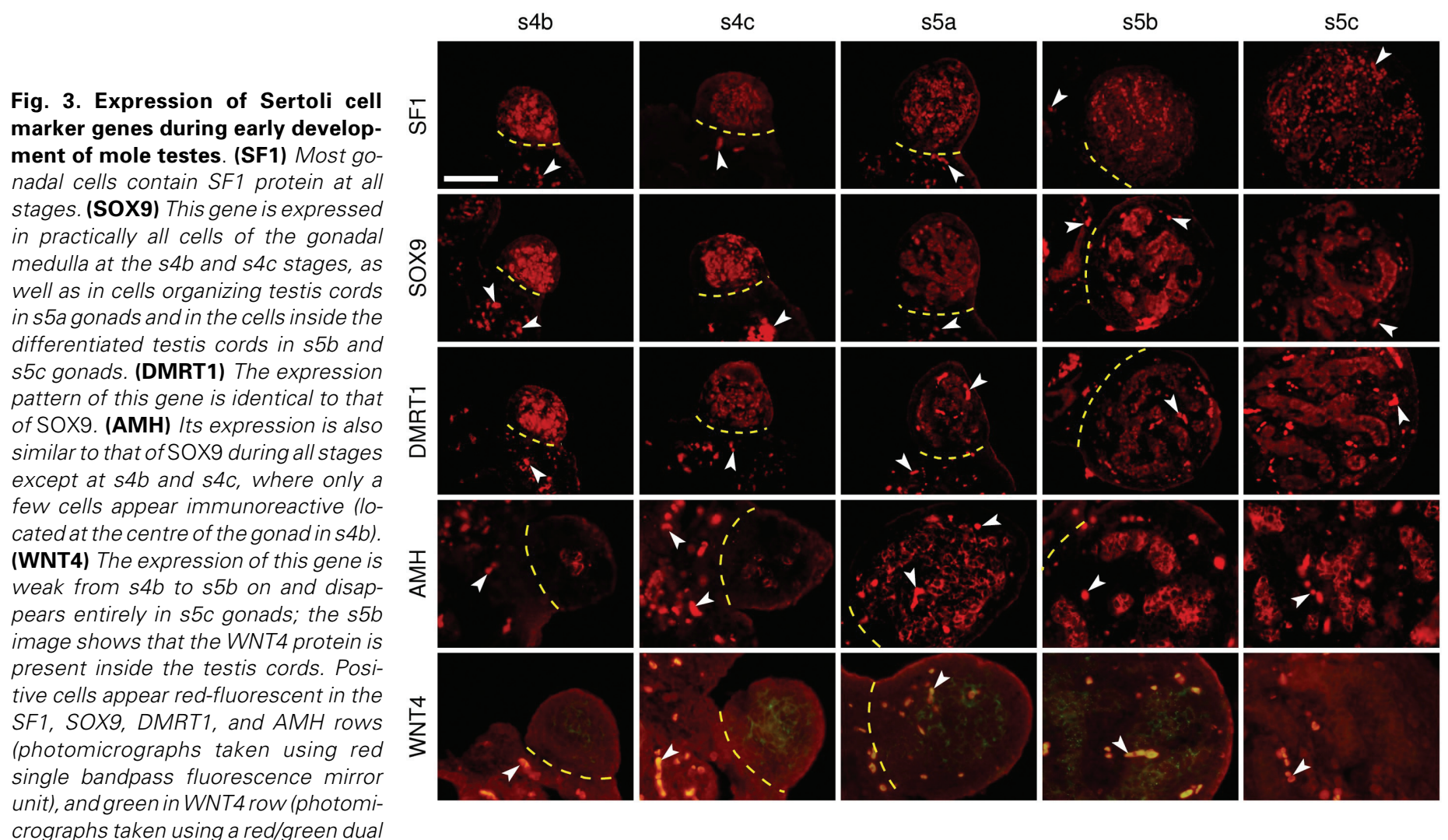
bandpass fluorescence mirror unit). Yellow dotted lines mark the gonad-mesonephros border line. Scale bar represent $150 \mu \mathrm{m}$ in the AMH and WNT4 row, and $100 \mu \mathrm{m}$ in all the rest. Arrowheads point erythrocytes, which appear autofluorescent in all immunofluorescence pictures.

see that the immunoreactive cells are located inside the testis cords and are probably Sertoli cells.

\section{Expression of cell migration markers during testis differen- tiation in male moles}

PDGFR- $\alpha$ shows a transient expression during testis differentiation in male moles (Fig. 4, first row). Some protein may be detected at the s4b stage but maximal immunoreactivity was found in s5a gonads. The expression clearly decreases one day later (s5b stage) and is completely absent at s5c. The remaining PDGFR- $\alpha$ protein observed in s5b gonads indicates that it is contained in the interstitial cells, outside the testis cords. MT1MMP metalloproteinase was detected in both gonads and mesonephros of $\mathrm{s} 4 \mathrm{~b}$ embryos, but few immunoreactive cells were observed in the borderline between these two organs at this stage (Fig. 4, second row). However, large quantities of strongly positive cells were observed in this region during the $s 5 \mathrm{a}$ and $\mathrm{s} 5 \mathrm{~b}$ stages. At s5c no MT1-MMP protein may be detected in the gonadal medulla, but a strong expression persists at the cortical region, just beneath the coelomic epithelium.

\section{Formation of the testis cords in male moles}

The organization of the testis cords in male moles was studied by detecting laminin, a protein that accumulates in the basal lamina of the testis cords, and AMH, a marker for Sertoli cells (Fig. 5). Laminin deposits appear in $s 4 b$ gonads around the first Sertoli cells expressing $A M H$, although cord structures are not yet visible at this stage. Cords are still disorganized at $\mathrm{s} 4 \mathrm{c}$, although some cord-like structures were recognizable in s5a gonads; $\mathrm{AMH}-$ positive cells were located inside these differentiating testis cords. Well differentiated, elongated, true testis cords were first observed in $\mathrm{s} 5 \mathrm{~b}$, and were evident in $\mathrm{s} 5 \mathrm{c}$ embryos, where a well formed basal lamina encloses groups of several $A M H$-expressing Sertoli cells. Cord anastomosis is frequent at early stages and decreases as testis differentiation proceeds, and therefore it is absent in $\mathrm{s} 5 \mathrm{c}$ gonads.

\section{Leydig cell differentiation in male moles}

The timing of Leydig cell differentiation in male moles was studied by immunofluorescence, using an antibody specific for the Leydig cell marker cytochrome P450scc (side-chain cleavage), which is present in the cytoplasm of Leydig cells, as shown in Figure 6A. The first Leydig cells differentiate at the s5c stage, where a few of them appear scattered in the interstitial areas of the testis. No Leydig cells were detectable in testes of the previous stage $s 5 \mathrm{~b}$. The number of Leydig cells increases during the next two stages, s6 and s7, where large patches of them originate, and persist until puberty (not shown). Leydig cells are also strongly immunoreactive against the SF1 antibody (Fig. 3, first row; s5c stage), whereas Sertoli cells, located inside the testis cords, appear clearly less immunoreactive (Fig. 3, first row). Double immunostaining with $\mathrm{AMH}$, a Sertoli cell marker, and SF1, which marks both Sertoli and steroidogenic cell precursors, evidences that Leydig cell precursors are present in the testes of $\mathrm{s} 5 \mathrm{a}$ and $\mathrm{s} 5 \mathrm{~b}$ 

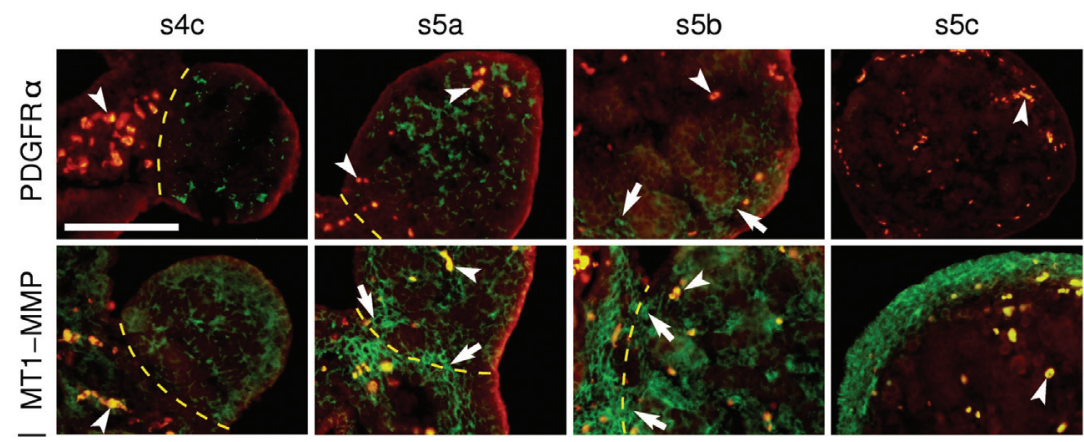

Fig. 4. Expression of genes involved in cell migration during the first stages of mole testis development. (Pdgfr- $\boldsymbol{\alpha}$ ) This gene is expressed from s4c to s $5 b$, but not at the $s 5 c$ stage, reaching its peak at s5a; the remaining expression in $55 b$ gonads evidences that it occurs in the interstitial cells, outside the testis cords (arrows). (MT1. MMP) Cells expressing this gene may be seen in both gonad and mesonephros at all stages analysed, but their distribution is stage-dependent: masses of strongly immunoreactive cells stretching out across the gonad-mesonephros borderline were observed at the s5a and s5b stages (arrows), but not at s4c; expression in deep gonadal regions occurs in the interstitial cells of s5a and s5b testes; at s5c, MT1-MMP expression is restricted to the peripheral layer of testicular cells forming the tunica albuginea. Yellow dotted lines mark the gonad-mesonephros borderline. Photomicrographs were taken using a red/green dual bandpass fluorescence mirror unit. Scale bar represents 200 $\mu \mathrm{m}$ in the PDGFR $\alpha$-s5c picture and $100 \mu \mathrm{m}$ in the rest. Arrowheads point out autofluorescent erythrocytes.

embryos (Fig. 6B), as they express $S F 1$, but not $A M H$. This figure clearly shows that the number of Leydig cell precursors increases in the transition between these two stages. However, no Leydig cell precursors seem to exist at previous stages ( $44 b$ and c), when all cells immunoreactive for SF1 also expresS SOX9, and are thus Sertoli cells (Fig. 3, first to third rows).

\section{Discussion}

\section{Sertoli cells differentiate very early in the mole as compared to the mouse}

In the mouse, Sertoli cells differentiate from epithelial-type cells of the undifferentiated gonadal primordium, in a two-step process. In the first step, the testis- determining gene Sry is activated in these cells at $10.5 \mathrm{dpc}$ (for a review, see Polanco and Koopman, 2007), and the pro-testis gene Sox9 express afterwards so that before $11.5 \mathrm{dpc}$ these cells have become pre-Sertoli cells (Sekido etal., 2004; Wilhelm etal., 2005). In the second step, fully functional Sertoli cells differentiate coinciding with the production of Amh and the formation of testis cords between 11.5 and $12.5 \mathrm{dpc}$ (see Behringer et al., 1990; Brennan and Capel, 2004). Hence, differentiated Sertoli cells become visible two days after the onset of the formation of the mouse genital ridge. In the mole, however, fully differentiated Sertoli cells begin to appear in the just-formed, morphologically undifferentiated gonadal primordium (s4b stage), where a few cells may be seen expressing both SOX9and AMH. In a previous study (Zurita et al., 2003), we were unable to detect $A M H$ transcripts in $\mathrm{s} 4$ and s5a mole testes by RT$\mathrm{PCR}$, probably due to the scarcity of material from these stages in that study. The expression patterns of the other three genes investigated in the present study, SF1, DMRT1, and WNT4, coincide with those described for these genes in the mouse Sertoli cells, and support the Sertolian nature of those cells in the mole gonad. The first cells expressing SF1, SOX9 and $A M H$ genes in $\mathrm{s} 4 \mathrm{~b}$ embryos are located in the central region of the gonad, whereas the cells located outside this region do express $S F 1$ and SOX9, but not $A M H$ (thus they are pre-Sertoli cells). Two days later, at the 55 a stage, most gonadal cells expressed all three genes. This indicates that, in the mole, the expression of $S F 1$ and SOX9 precedes that of $A M H$, corroborating the hypothesis that SOX9 interacts with SF1 to upregulate the expression of $A M H$, as has been suggested for mammals (Arango et al., 1999), but not for the chicken (Oreal et al., 1998) or the alligator (Western et al., 1999) where $A M H$ activates before SOX9. Our results also suggest that Sertoli cell differentiation occurs in the mole according to a centrifugal wave that proceeds rapidly through the dorsoventral axis of the gonad, between the $s 4 b$ and $s 5 a$ stages. A similar situation has been described for the mouse testis, where Sryalso activates following a dynamic wave through the anteroposterior axis of the gonad, moving from the centre to the poles (Bullejos and Koopman, 2001). It is not known, however, whether the mouse Amh activates according to the same pattern, or whether mole Sertoli cells follow a centre-to-poles differentiation wave.

\section{Testicular cords of the mole testis organize slowly and after Sertoli cell differentiation}

Our results in the mole show that cord formation takes place
Fig. 5. Formation of the testis cords in male moles. Merged images of laminin + AMH double sequential immunostaining of mole gonads in five developmental stages from $s 4 b$ to $s 5 c$ are shown. The first laminin deposits appear as early as the s4b stage, located around the first few differentiated Sertolicells. Testis cord-like structures are not detectable at $s 4 c$, and first appear ats5a. Closed, well-formed testis cords are first observed in $s 5 b$ embryos, when all Sertoli cells (AMH-positive) appear enclosed inside a testis cord, and appear more clearly defined at s5c stage. Fluorescence colours are red for laminin and green for $\mathrm{AMH}$. Arrows point out cord-like structures and testis cords in s5a and s5b-c, respectively. Scale bar represents $40 \mu \mathrm{m}$. s4b s4c
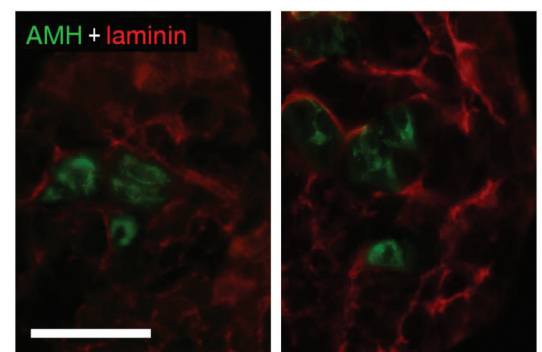

s5a

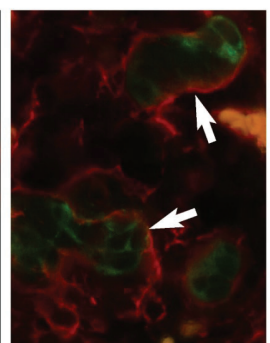

$\mathrm{s} 5 \mathrm{~b}$

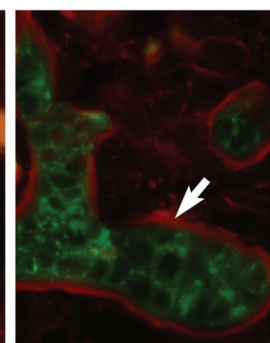

$\mathrm{s} 5 \mathrm{c}$

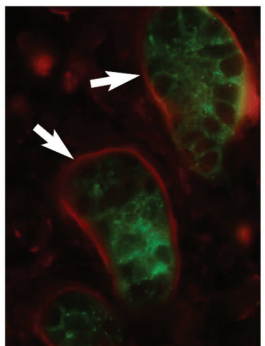


A
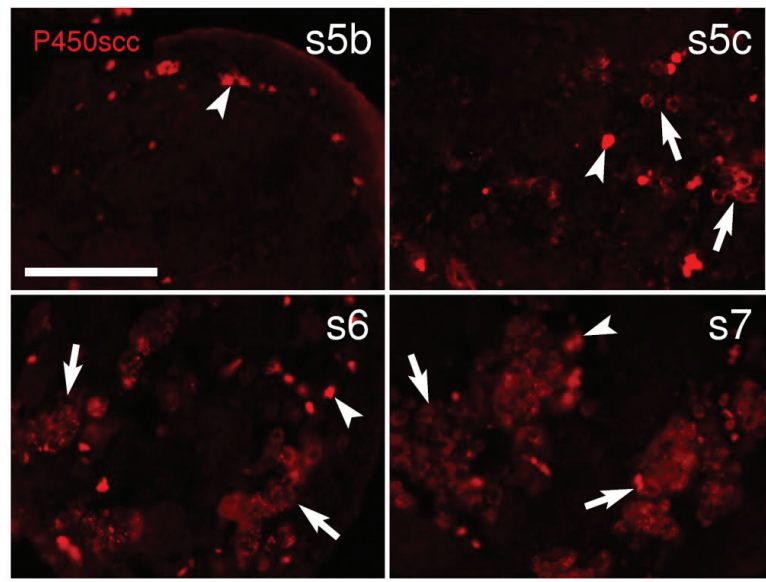

B
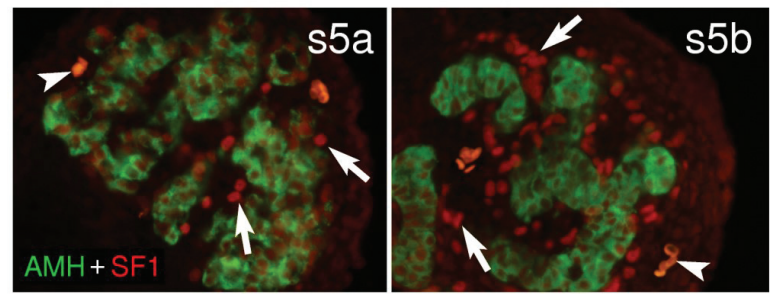

Fig. 6. Differentiation of Leydig cells in the mole testis. (A) Immunostaining for the cytochrome P450scc shows that the first Leydig cells appear at the s5c stage (arrows), as no interstitial cell is immunoreactive in the previous stage, s5b. The number of differentiated Leydig cells increases during the two following stages 56 and $s 7$, where large patches of them are formed (arrows). (B) Merged images of double, sequential immunostaining for the Sertoli cell marker AMH (cytoplasmic green fluorescence) and the Sertoli- and steroidogenic cell marker SF1 (nuclear red fluorescence), evidences that Leydig cell precursors (expressing SF1 but not $\mathrm{AMH}$; arrows) are present in the male gonad of s5a and s5b mole embryos. Red fluorescence is stronger in Leydig cell precursors than in Sertoli cells. The number of Leydig cells increases between s5b and s5c. Scale bar represents $100 \mu \mathrm{m}$. Arrowheads point to autofluorescent erythrocytes in all pictures.

slowly, throughout a three- day period, from the s4b stage, where the first laminin deposits appear, to the s5b stage, where testis cords are histologically recognizable for the first time, as described previously (Barrionuevo et al., 2004a). Immunofluorescence images of Sertoli cell markers in the mole (SF1, SOX9, AMHand DMRT1)reveal structures resembling cords in s5a testes, although at this stage, testis cords are not yet histologically defined. Similarly, laminin immunostaining shows that the organization of some cords is quite advanced by the s5a stage (Fig. 5). These data indicate that, even though testis cords are not histologically recognizable before the s5b stage, functional compartments do already exist in the gonads of $\mathrm{s} 5 \mathrm{a}$ mole embryos, but not at earlier stages. This proves consistent with the hypothesis that cords differentiate in the murine testis before they become morphologically conspicuous, and that it is the interposition of less dense tissue composed of migrating and proliferating mesenchymal cells that allows for the identification of those cords (Merchant-Larios and Taketo, 1991; Merchant-Larios et al., 1993).

The formation of testis cords is crucial for the development and functioning of the male gonad. In the mouse embryo, it has been ascertained that both Sertoli cell differentiation and testis cord formation occur in just one day, between 11.5 and 12.5 $\mathrm{dpc}$, and that these two events are the results of mesonephric cell migration (Tilmann and Capel., 1999). Magre and Jost (1984) suggested that Sertoli cells can differentiate in the absence of testis cords, and Yao and Capel (2002) have provided evidence to further corroborate this presumption. In the mole, on the other hand, Sertoli cell differentiation is very fast, whereas testis cord formation is very slow in comparison with the mouse, thus rendering it unlikely that these two events share a common origin. Rather, the sequence of events observed in the mole clearly suggests that testis cord formation requires the presence of previously differentiated Sertoli cells.

\section{Sertoli cell differentiation does not depend on mesonephric cell migration}

Cell migration is a key event in gonad development. Although there is intragonadal cell movement at different stages of testis development (see MT1-MMP immunostaining at s4b and s5c stages in Fig. 4), the migration of mesonephric cells to the gonad prior to the formation of the testis cords is particularly important (Buehr et al., 1993). In the mouse, it has been suggested that the differentiation of Sertoli cells, the formation of the testis cords and the establishment of the testis-specific vascular system require such migration (Tilmann and Capel, 1999; Brennan et al., 2002). Accordingly, a prerequisite for this hypothesis is that mesonephric cell migration must precede all these developmental events.

Due to the specific nature of our study material, which consists in gonads of mole embryos obtained from pregnant female moles captured in the wild, this material is very scarce, and therefore in vitro organ culture experiments, which might provide tangible evidence for mesonephric cell migration, are unlikely to be a feasible project with this species. Thus, although the presence of structures such as a profuse vasculature (our unpublished data), and such cell types as peritubular myoid cells (Barrionuevo et al., 2004), known to rely upon mesonephric cell migration, lead to the assumption that it also occurs in the mole, we are unable to find direct evidence pinpointing the time when this cell migration takes place. However, it is possible to know when migration is absent. Here we have investigated the presence of MT1-MMP, a migrating cell marker (see Gálvez et al., 2001), and PDGFR $\alpha$, a key component of a signalling pathway involved in $X Y$ gonadspecific cell proliferation, mesonephric cell migration and Leydig cell differentiation in the mouse (Brennan et al., 2003; Ricci et al., 2004; see Fig. 4). The expression of MT1-MMP does not indicate by itself that migration occurs, as it may also reflect local, non-migratory, cell movement, but the absence of these markers constitutes clear and direct evidence that no migration has taken place. Thus, we provide evidence that no cells migrate from the mesonephros to the gonads in mole embryos at the $\mathrm{s} 4 \mathrm{c}$ or previous stages, as $P D G F R \alpha$ expression is very low, and MT1-MMPexpresses inside the gonad, but not in the mesonephros-gonad border or in adjacent mesonephric areas (see Fig. 4). Hence, considering that cells in the gonads of $\mathrm{s} 4 \mathrm{~b}$ and s4c mole embryos do express both $S O X 9$ and $A M H$ Sertolian markers, we conclude that mesonephric cell migra- 
tion does not precede Sertoli cell differentiation and that it is not necessary for the endocrine differentiation of Sertoli cells.

\section{PDGFR- $\alpha$-independent intragonadal cell movement/migra- tion accompanies the formation of the tunica albuginea of the testis}

The tunica albuginea testis is the major component of the capsule of mammalian testes. It is composed mainly of fibroblasts interspersed with collagen fibres (see Setchell et al., 1994), and contains contractile cells (Middendorff et al., 2002). Different aspects of the function of the tunica albuginea have been investigated, including 1) promotion of sperm export to the epididymis, 2) contribution to maintaining the intratesticular pressure and 3) control of the testicular blood flow (for a review, see Setchell et al., 1994), but little is known about its development. In the mouse, the tunica albuginea begins to form at $12.5 \mathrm{dpc}$, once the testis cords have organized (Karl and Capel, 1998). In the mole, morphological differentiation of the tunica albuginea occurs between s 6 and s8 stages (Barrionuevo et al., 2004a), but in the present paper we report that the process begins one day earlier, at the s5c stage. This process involves mainly the production of collagen fibres and the differentiation of the cells forming the basement membrane layer underlying the coelomic epithelium, which flatten and dispose parallel to the surface epithelium. These shape changes probably require active cell movement, which is consistent with our finding that these cells show a marked expression of the migration marker MT1-MMP. Unlike mesonephric cell migration, these cell movements start just as PDFGR- $\alpha$ is repressed in the testis, which indicates that intragonadal cell migration/movement accompanying the tunica albuginea differentiation is not mediated by $P D F G R-\alpha$ signalling.

\section{Mole embryonic Leydig cells differentiate once WNT4 and PDGFR- $\alpha$ are repressed}

The differentiation of mole embryonic Leydig cells begins at the s5c stage, when P450sccexpression indicates that testosterone is being produced. However, we have shown that their cell precursors were already present in the testis interstitial regions two days before, at stages s5a and s5b, but not in previous stages. In the mouse, it has been demonstrated that Leydig cell precursors are present in the gonads of $11.5 \mathrm{dpc}$ embryos at least one day before the differentiation of these cells at $12.5 \mathrm{dpc}$ (Brennan et al., 2003). This raises the question as to why Leydig cell differentiation does not occur as soon as the precursors are present both in moles and in mice. Recent papers have reported that the presence of Leydig cells in the gonad is controlled by at least four genes involved in different signalling pathways: PDFGR$\alpha, D H H, A R X$ and WNT4. The first three genes promote the formation of Leydig cells in testes (Kitamura et al., 2002; Yao et al., 2002; Brennan et al., 2003), whereas the latter gene inhibits their formation in ovaries (Jeays-Ward et al., 2003).

Brennan etal. (2003) have shown that Leydig cell development requires Pdfgr- $\alpha$, and endorse the hypothesis that this gene is involved in a signalling pathway which promotes the expansion of Leydig cell precursors. However, mouse data did not provide concluding evidence as to whether Pdfgr- $\alpha$ is also involved in Leydig cell differentiation. The expression pattern of the mole PDFGR- $\alpha$ gene supports the hypothesis that this gene is involved in the maintenance and/or proliferation of Leydig cell precursors, but clearly rules out the possibility that it is responsible for Leydig cell differentiation, as PDFGR- $\alpha$ expression coincides at the $\mathrm{s} 5 \mathrm{a}$ and $\mathrm{s} 5 \mathrm{~b}$ stages with the presence of Leydig cell precursors, but ceases just before Leydig cell differentiation takes place at s5c. The fact that PDFGR- $\alpha$ is also involved in cell migration, is consistent with the hypothesis that the precursors of Leydig cells migrate from the mesonephros to the gonad, together with those of peritubular myoid cells and endothelial cells.

Vainio et al.,1999) identified WNT4 as part of the signalling pathway responsible for the absence of Leydig cells in female gonads, and suggested that this gene suppresses the differentiation of the Leydig cell precursors already present in the gonad. Contrarily, based on their observations in transgenic XY mice expressing Wnt4, Jeays-Ward et al. (2003) have shown that one function of this gene is to suppress the migration of a few steroidogenic adrenal cells within the gonad. In the present paper we show that WNT4 expresses in the developing mole testis from the $s 4 b$ to $s 5 b$ stages. This expression pattern is consistent with the function of WNT4 in suppressing the differentiation of preexisting Leydig cell precursors, as Leydig cell differentiation occurs just when WNT4 expression ceases, but not with the preclusion of mesonephric cell migration, as most cell migration probably occurs during the s5a and s5b stages, which coincides with the expression timing of WNT4. Nevertheless, in mouse female gonads, WNT4 represses mesonephric cell migration through follistatin (Yao et al., 2004); therefore, the expression of WNT4 in mole gonads at stages where cell migration is taking place is not surprising, as no follistatin has been detected in those gonads (our unpublished data). It also bears pointing out that the WNT4 expression observed in the gonads of male moles is not as intense as that found in females (unpublished). In this sense, it is necessary to consider that the expression level detected in males might have no functional effect. Quantitative RT-PCR analyses currently being undertaken in our lab may shed light on this issue.

\section{Concluding remarks}

The laboratory mouse permits the use of the most powerful research tools in modern biology, including transgenesis and targeted mutagenesis. The logical consequence is that in the better part of the ongoing research in mammalian developmental biology, the laboratory mouse is used as an animal model. However, in some instances, the results of this research cannot be extrapolated to the rest of mammals -including humans- since the mouse itself is the exception in these cases. A case in point is the genetic system controlling sex determination: the mouse Srygene is unique among mammals with regard to its structure and expression pattern (Capel et al., 1993). Hence, other mammalian species must be investigated to test the degree of evolutionary conservation of the developmental processes discovered in the mouse. One of the main difficulties found in research on gonad development in the mouse is that many complex genetic and cellular events take place almost simultaneously between 11.5 and $12.5 \mathrm{dpc}$, making it difficult to establish the sequence of those events, which is necessary to postulate cause-effect relationships. In other mammals, this very same process is much slower, which facilitates the work. This is the case for testis organogenesis in the mole, which we have depicted in this paper. Our results from studying the mole provide evidence that the 
TABLE 1

\section{ANALYSED MATERIAL CLASSIFIED ACCORDING TO DEVELOPMENTAL STAGES}

\begin{tabular}{cccc} 
Developmental stage & Age $(\mathrm{dpc})$ & No. of litters & No. of male embryos analysed \\
\hline s4b & 15 & 3 & 5 \\
s4c & 16 & 2 & 4 \\
s5a & 17 & 4 & 7 \\
s5b & 18 & 4 & 7 \\
s5c & 19 & 3 & 5 \\
s6 & $19-21$ & 2 & 3 \\
s7 & $21-23$ & 2 & 3 \\
\hline
\end{tabular}

spatio-temporal pattern of testis development is not perfectly conserved in mammals, since we found differences with respect to the mouse testis organogenesis. This fact is even more significant when we consider that, apart from the mouse, the mole is probably the one of the best-known mammalian species in terms of the genetic control of testis development, implying that more peculiarities would be found if more species were investigated.

\section{Materials and Methods}

\section{Material analysed}

A total of 34 male embryos of the mole species T. occidentalis were analysed. As moles do not breed in captivity, embryonic gonad collection required the dissection of wild pregnant female moles. They were captured in poplar groves around Chauchina and Santa Fé (Granada province, southern Spain), as described previously (Barrionuevo et al., 2004a). Captures were made under annual permission granted by the Andalusian Environmental Council. Handling followed the guidelines and approval of the 'Ethical Committee for Animal Experimentation' of the University of Granada. Table 1 summarizes the material analysed according to the developmental stages described by Barrionuevo et al. (2004a and b) for this species. However, in this study, we have distinguished three new substages in the s4 stage (s4a-c), in accordance with our new findings in these embryos. At the s4a stage, mole embryos show no gonad development, at $s 4 b$ the gonad emerges, and at $s 4 c$ it remains morphologically undifferentiated.

Five litters of Swiss mouse embryos, from 10.5 to $14.5 \mathrm{dpc}$, provided by the Laboratory Animal Production Unit of the University of Granada, were used to establish the equivalences between the developmental stages of the mole and the mouse throughout the gestation period in which gonad differentiation occurs in both species, and to perform immunofluorescence analyses in order to test the specificity of the antibody produced in our laboratory (see below).

\section{Developmental staging and sexing of the embryos}

After capture, pregnant females were detected by abdominal palpation, and the developmental stages of the embryos were thus estimated by the size of the uterine swellings. Accurate determination of the developmental stage of each litter was performed after dissection, based on the values of crown-rump length (CRL) and body mass, and the morphology of major external structures, according to Barrionuevo et al. (2004b). As embryos of the s4a-c and s5a stages are not sexually differentiated, identification of individual sex based on morphological criteria is not possible. These embryos were sexed by performing sexchromatin preparations of amniotic cells, which were analysed for the presence (females) or absence (males) of the Barr's body. Sex-chromatin preparations were made as in Jiménez et al. (2000).

\section{Immunofluorescence}

After the embryonic gonads were dissected out, one was fixed in paraformaldehyde solution (4\%) overnight. The other gonad from each embryo was immediately frozen in liquid nitrogen for further purification of RNA samples. After having been washed in PBS, fixed samples were dehydrated, embedded in paraffin wax and sectioned, following standard procedures. Gene-expression analyses were performed by immunofluorescence. De-waxed preparations were exposed to specific primary antibodies for several $\mathrm{h}$, then to fluorochrome-conjugated secondary antibodies, as summarized in Table 2. In some instances, double, sequential immunostaining was performed with two different primary antibodies, and the resulting images were then merged using the Gimp program. Two complete sets of gonads at all developmental stages were used with each primary antibody in order to test the reproducibility of the results. For the more controversial results, we repeated the immunofluorescence technique, using up to five different gonads, when available.

\section{Molecular cloning, sequencing and antibody production}

Commercially available antibodies for the human or mouse protein WNT4 were not immunoreactive against the corresponding protein from the mole. Therefore, we needed to produce a new mole-specific WNT4 antiserum. A fragment of the mole WNT4 gene was PCR amplified and sequenced. For the PCR amplification, forward (5'-TTG TGG ATG TGC GGG AGA G-3') and reverse (5'-TGT GTG CGG CTT GAA CTG TG-3') primers were selected from among evolutionarily conserved sequences. The 293 base pair (bp) PCR product was sequenced in an automatic Applied Biosystem 3100-Avant Genetic Analyser. The sequence obtained was translated in silico, and the "antigenic" software from the

TABLE 2

\section{PRIMARY ANTIBODIES USED IN THIS STUDY}

\begin{tabular}{|c|c|c|c|}
\hline Gene ${ }^{1}$ product & Description/Utility & antibody source & references $^{2}$ \\
\hline AMH & Anti-Müllerian hormone. Sertoli cell marker. & goat polyclonal, raised against human protein & Santa Cruz Biotechnology Ref. sc-6886 \\
\hline DMRT1 & Zinc-finger-like DNA-binding motif protein. Sertoli and germ cell marker. & rabbit polyclonal raised against mouse protein & Dr. Sylvana Guioli \\
\hline Laminin & Basal lamina protein. Testis cord formation marker. & rabbit polyclonal, raised against mouse protein & SIGMA Ref. L9393 \\
\hline MT1-MMP & Membrane type 1-matrix metalloproteinase. Migrating cell marker. & mouse monoclonal, raised against human protein & Dr. Alicia G. Arrollo \\
\hline P450 scc & Androgen metabolism cytochrome. Leydig cell marker. & goat polyclonal, raised against human protein & Santa Cruz Biotechnology Ref. sc- 18043 \\
\hline $\operatorname{PDGFR} \alpha$ & $\alpha$ receptor of the platelet-derived growth factor. Indirect migration signalling. & rabbit polyclonal, raised against human protein & Santa Cruz Biotechnology Ref. sc-338 \\
\hline SF1 & Steroidogenic factor. Sertoli and Leydig cell marker. & rabbit polyclonal, raised against mouse protein & Dr. Ken Morohashi \\
\hline sox9 & Transcription factor SOX. Sertoli cell marker. & rabbit polyclonal, raised against human protein & Santa Cruz Biotechnology Ref. sc-20095 \\
\hline WNT4 & Signalling molecule involved in the ovarian development. & rabbit polyclonal, raised against mole protein & Developed by the authors \\
\hline
\end{tabular}

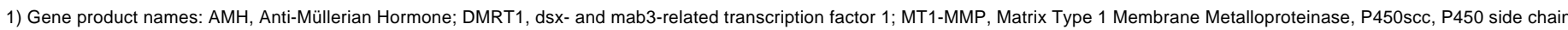

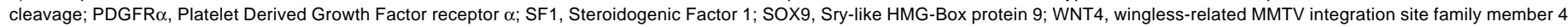

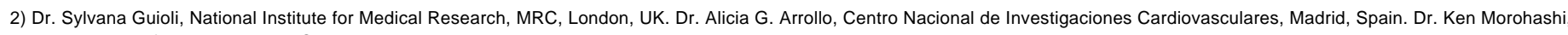
National Institute for Basic Biology, Okazaki, Japan. 
EMBO package (Rice etal., 2000) was used to identify potential antigenic sites. The peptide sequence RVECKCHGVSGSCEV from the mole WNT4 protein was synthesised and used to immunize rabbits. One New Zealand rabbit, 60 days post partum (dpp), was immunized with the mole WNT4 peptide, following standard procedures. The resulting serum was titrated by performing periodical ELISA tests, and the rabbit was bled when titres reached values above $1 / 450$. This antibody was tested by western blotting and immunofluorescence, following standard procedures.

\section{Acknowledgements}

The authors would like to thank Dr Antonio Osuna and Rogelio Palomino for help in producing and testing the WNT4 antibody; Drs Robin Lovell-Badge and Blanche Capel for permitting several members of our group to visit their labs, and their collaborators for support and training; Drs. Sylvana Guioli, Alicia G. Arrollo and Ken Morohashi, for kindly providing us with antibodies; D de la Cruz and FM Real for assistance in captures; and the Andalusian Consejería de Medio Ambiente for capture permits. This work was supported by Junta de Andalucia through Group PAICVI-109, and the Spanish Dirección Generalde Investigación through projects BOS2002-00657 and CGL2004-00863/BOS.

\section{References}

ARANGO, N., LOVELL-BADGE, R. and BEHRINGER, R. (1999). Targeted mutagenesis of the endogenous mouse Mis gene promoter: in vivo definition of genetic pathways of vertebrate sexual development. Cel/99: 409-419.

BARRIONUEVO, F., ZURITA, F., BURGOS, M. and JIMÉNEZ, R. (2004a). Testislike development of gonads in female moles. New insights on mammalian gonad organogenesis. Dev. Biol. 268: 39-52.

BARRIONUEVO, F., ZURITA, F., BURGOS, M. and JIMÉNEZ, R. (2004b). Developmental stages and growth rate of the mole Talpa occidentalis (Insectivora, Mammalia). J. Mammal. 85: 120-125.

BEHRINGER, R., CATE, R., FROELICK, G., PALMITER, R. and BRINSTER, R. (1990). Abnormal sexual development in transgenic mice chronically expressing mullerian inhibiting substance. Nature $345: 167-170$.

BRENNAN, J. and CAPEL, B. (2004). One tissue, two fates: molecular genetic events that underlie testis versus ovary development. Nat. Rev. Genet. 5: 509_ 521.

BRENNAN, J., KARL, J. and CAPEL, B. (2002). Divergent vascular mechanisms downstream of Sry establish the arterial system in the XY gonad. Dev. Biol. 244: 418-428.

BRENNAN, J., TILMANN, C. and CAPEL, B. (2003). Pdgfr-alpha mediates testis cord organization and fetal Leydig cell development in the XY gonad. Genes. Dev. 17: 800-810.

BUEHR, M., GU, S. and MCLAREN, A. (1993). Mesonephric contribution to testis differentiation in the fetal mouse. Development 117: 273-281.

BULLEJOS, M. and KOOPMAN, P. (2001). Spatially dynamic expression of Sry in mouse genital ridges. Dev. Dyn. 221: 201-205

CAPEL, B. (2000). The battle of the sexes. Mech. Dev. 92: 89-103.

CAPEL, B., SWAIN, A., NICOLIS, S., HACKER, A., WALTER, M., KOOPMAN, P., GOODFELLOW, P. and LOVELL-BADGE, R. (1993). Circular transcripts of the testis-determining gene Sry in adult mouse testis. Cel/73: 1019-1030.

CHABOISSIER, M., KOBAYASHI, A., VIDAL, V., LUTZKENDORF, S., VAN DE KANT, H., WEGNER, M., DE ROOIJ, D., BEHRINGER, R. and SCHEDL, A. (2004). Functional analysis of Sox8 and Sox9 during sex determination in the mouse. Development 131: 1891-1901.

CLARK, A., GARLAND, K. and RUSSELL, L. (2000). Desert hedgehog (Dhh) gene is required in the mouse testis for formation of adult-type Leydig cells and normal development of peritubular cells and seminiferous tubules. Biol. Reprod. 63: $1825-1838$.

GÁLVEZ, B.G., MATIAS-ROMAN, S., ALBAR, J.P., SANCHEZ-MADRID, F. and ARROYO, A.G. (2001). Membrane type 1-matrix metalloproteinase is activated during migration of human endothelial cells and modulates endothelial motility and matrix remodeling. J. Biol. Chem. 276: 37491-37500.
JEAYS-WARD, K., HOYLE, C., BRENNAN, J., DANDONNEAU, M., ALLDUS, G., CAPEL, B. and SWAIN, A. (2003). Endothelial and steroidogenic cell migration are regulated by WNT4 in the developing mammalian gonad. Development 130 : 3663-3670

JIMÉNEZ, R., BARRIONUEVO, F.J. and BURGOS, M. (2000). A faster procedure for preparing amniotic cells for sexing embryos. Technical Tips Online. T02062. (http://research.bmn.com/tto/).

JIMÉNEZ, R., BURGOS, M., SÁNCHEZ, A., SINCLAIR, A., ALARCON, F., MARIN J., ORTEGA, E. and DÍAZ DE LA GUARDIA, R. (1993). Fertile females of the mole Talpa occidentalis are phenotypic intersexes with ovotestes. Development 118: 1303-1311.

JOST, A. (1947). Recherches sur la differenciation sexuelle de l'embryon de lapin. Arch. Anat. Microsc. Morphol. Exp. 36: 271-315.

KANAI, Y., KAWAKAMI, H., TAKATA, K., KUROHMARU, M., HIRANO, H. and HAYASHI, Y. (1992). Involvement of actin filaments in mouse testicular cord organization in vivo and in vitro. Biol. Reprod. 46: 233-245.

KARL, J. and CAPEL, B. (1998). Sertoli cells of the mouse testis originate from the coelomic epithelium. Dev. Biol. 203: 323-333.

KITAMURA, K., YANAZAWA, M., SUGIYAMA, N., MIURA, H., LIZUKA-KOGO, A., KUSAKA, M., OMICHI, K., SUZUKI, R., KATO-FUKUI, Y., KAMIIRISA, K., MATSUO, M., KAMIJO, S., KASAHARA, M., YOSHIOKA, H., OGATA, T., FUKUDA, T., KONDO, I., KATO, M., DOBYNS, W., YOKOYAMA, M. and MOROHASHI, K. (2002). Mutation of ARX causes abnormal development of forebrain and testes in mice and X-linked lissencephaly with abnormal genitalia in humans. Nat. Genet. 32: 359-369.

MAGRE, S. and JOST, A. (1984). Dissociation between testicular organogenesis and endocrine cytodifferentiation of Sertoli cells. Proc. Natl. Acad. Sci. USA. 81 7831-7834.

MARTINEAU, J., NORDQVIST, K., TILMANN, C., LOVELL-BADGE, R. and CAPEL, B. (1997). Male-specific cell migration into the developing gonad. Curr. Biol. 7: 958-968.

MCLAREN, A. (2003). Primordial germ cells in the mouse. Dev. Biol. 262: 1-15.

MERCHANT-LARIOS, H. and TAKETO, T. (1991). Testicular differentiation in mammals under normal and experimental conditions. J. Electron. Microsc. Tech. 19: 158-171.

MERCHANT-LARIOS, H., MORENO-MENDOZA, N. and BUEHR, M. (1993) The role of the mesonephros in cell differentiation and morphogenesis of the mouse fetal testis. Int. J. Dev. Biol. 37: 407-415.

MIDDENDORFF, R., MÜLLER, D., MEWE, M., MUKHOPADHYAY, A.K., HOLSTEIN, A.F. and DAVIDOFF, M.S. (2002). The tunica albuginea of the human testis is characterized by complex contraction and relaxation activities regulated by cyclic GMP. J. Clin. Endocrinol. Metab. 87: 3486-3499.

NEF, S. and PARADA, L.F. (1999). Cryptorchidism in mice mutant for InsI3. Nat Genet. 22(3): 295-299.

OREAL, E., PIEAU, C., MATTEI, M., JOSSO, N., PICARD, J., CARRE-EUSEBE, D. and MAGRE, S. (1998). Early expression of AMH in chicken embryonic gonads precedes testicular SOX9 expression. Dev. Dyn. 212: 522-532.

POLANCO, J.C. and KOOPMAN, P. (2007). Sry and the hesitant beginnings of male development. Dev. Biol. 302: 13-24.

PIERUCCI-ALVES, F., CLARK, A. and RUSSELL, L. (2001). A developmental study of the Desert hedgehog null mouse testis. Biol. Reprod. 65: 1392-1402.

RICCI, G., CATIZONE, A. and GALDIERI, M. (2004). Embryonic mouse testis development: role of platelet derived growth factor (PDGF-BB). J. Cell. Physiol. 200: 458-467.

RICE, P., LONGDEN, I. and BLEASBY, A. (2000). EMBOSS: The European Molecular Biology Open Software Suite. Trends. Genet. 6: 276-277.

ROSS, A. and CAPEL, B. (2005). Signaling at the crossroads of gonad development. Trends. Endocrinol. Metab. 16: 19-25.

RUBENSTEIN, N., CUNHA, G., WANG, Y., CAMPBELL, K., CONLEY, A., CATANIA K., GLICKMAN, S. and PLACE, N. (2003). Variation in ovarian morphology in four species of New World moles with a peniform clitoris. Reproduction 126 713-719.

SÁNCHEZ, A., BULLEJOS, M., BURGOS, M., HERA, C., STAMATOPOULOS, C. DÍAZ DE LA GUARDIA, R. and JIMÉNEZ, R. (1996). Females of four mole species of genus Talpa (Insectivora, Mammalia) are true hermaphrodites with 
ovotestes. Mol. Reprod. Dev. 44: 289-294.

SEKIDO, R., BAR, I., NARVAEZ, V., PENNY, G. and LOVELL-BADGE, R. (2004). SOX9 is up-regulated by the transient expression of SRY specifically in Sertoli cell precursors. Dev. Biol. 274: 271-279.

SETCHELL, B.P., MADDOCKS, S. and BROOKS, D.E. (1994). Anatomy, vasculature, innervation and fluids of the male reproductive tract. In: Knobil, E., Neill, J.D. (Eds), The Physiology of reproduction. Raven Press, New York,, pp. 10631175 .

SINCLAIR, A., BERTA, P., PALMER, M., HAWKINS, J., GRIFFITHS, B., SMITH, M., FOSTER, J., FRISCHAUF, A., LOVELL-BADGE, R. and GOODFELLOW, P. (1990). A gene from the human sex-determining region encodes a protein with homology to a conserved DNA-binding motif. Nature 346: 240-244.

TILMANN, C. and CAPEL, B. (1999). Mesonephric cell migration induces testis cord formation and Sertoli cell differentiation in the mammalian gonad. Development 126: 2883-2890.

TUNG, P. and FRITZ, I. (1987). Morphogenetic restructuring and formation of basement membranes by Sertoli cells and testis peritubular cells in co-culture: inhibition of the morphogenetic cascade by cyclic AMP derivatives and by blocking direct cell contact. Dev. Biol. 120: 139-153.

VAINIO, S., HEIKKILA, M., KISPERT, A., CHIN, N. and MCMAHON, A. (1999). Female development in mammals is regulated by Wnt-4 signalling. Nature 397 : 405-409.
VIDAL, V., CHABOISSIER, M., DE ROOIJ, D. and SCHEDL, A. (2001). Sox9 induces testis development in XX transgenic mice. Nat. Genet. 28: 216-217.

VIGIER, B., WATRIN, F., MAGRE, S., TRAN, D. and JOSSO, N. (1987). Purified bovine AMH induces a characteristic freemartin effect in fetal rat prospective ovaries exposed to it in vitro. Development 100: 43-55.

WESTERN, P., HARRY, J., GRAVES, J. and SINCLAIR, A. (1999). Temperaturedependent sex determination in the American alligator: AMH precedes SOX9 expression. Dev. Dyn. 216: 411-419.

YAO, H. and CAPEL, B. (2002). Disruption of testis cords by cyclopamine or forskolin reveals independent cellular pathways in testis organogenesis. Dev. Biol. 246: 356-365.

YAO, H., MATZUK, M., JORGEZ, C., MENKE, D., PAGE, D., SWAIN, A. and CAPEL, B. (2004). Follistatin operates downstream of Wnt4 in mammalian ovary organogenesis. Dev. Dyn. 230: 210-215.

YAO, H., WHORISKEY, W. and CAPEL, B. (2002). Desert Hedgehog/Patched 1 signalling specifies fetal Leydig cell fate in testis organogenesis. Genes. Dev. 16: $1433-1440$

ZURITA, F., BARRIONUEVO, F.J., BERTA, P., ORTEGA, E., BURGOS, M. and JIMÉNEZ, R. (2003). Abnormal sex-duct development in female moles: the role of antimullerian hormone and testosterone. Int. J. Dev. Biol. 47: 451-458.

\section{For all the latest on Pattern Formation research,} see our latest Special Issue edited by C.-M. Chuong and M.K. Richardson.

5 yr ISI Impact Factor $(2008)=3.271$

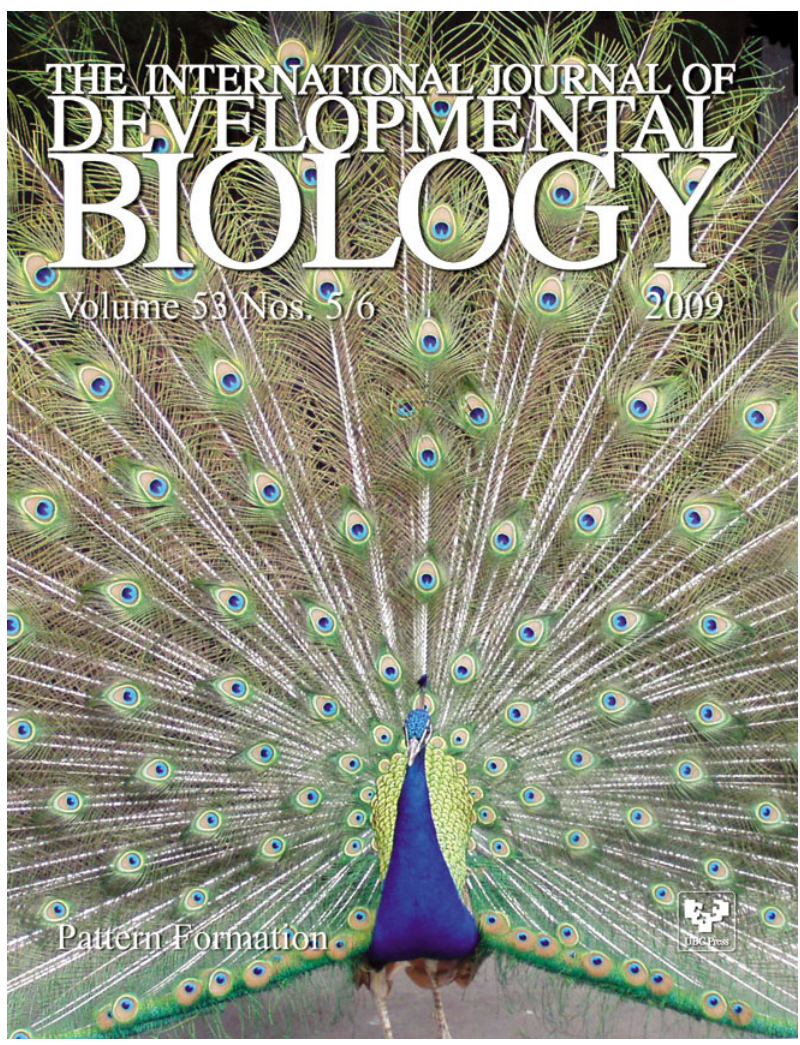




\section{Further Related Reading, published previously in the Int. J. Dev. Biol.}

See our recent Special Issue Fertilization, in honor of David L. Garbers and edited by Paul M. Wassarman and Victor D. Vacquier at: http://www.ijdb.ehu.es/web/contents.php?vol=52\&issue=5-6

Aard is specifically up-regulated in Sertoli cells during mouse testis differentiation Terje Svingen, Annemiek Beverdam, Pali Verma, Dagmar Wilhelm and Peter Koopman Int. J. Dev. Biol. (2007) 51: 255-258

Aard is specifically up-regulated in Sertoli cells during mouse testis differentiation Terje Svingen, Annemiek Beverdam, Pali Verma, Dagmar Wilhelm and Peter Koopman Int. J. Dev. Biol. (2007) 51: 255-258

Effects of FGF9 on embryonic Sertoli cell proliferation and testicular cord formation in the mouse Louise Willerton, Robert A. Smith, David Russell and Sarah Mackay Int. J. Dev. Biol. (2004) 48: 637-643

Developmental regulation of expression of Ran/M1 and Ran/M2 isoforms of Ran-GTPase in mouse testis. Pedro P López-Casas, Luis A López-Fernández, Mario Párraga, Dora B Krimer and Jesús del Mazo Int. J. Dev. Biol. (2003) 47: 307-310

Abnormal sex-duct development in female moles: the role of anti-Müllerian hormone and testosterone. Zurita F, Barrionuevo FJ, Berta P, Ortega E, Burgos M, Jiménez R. Int J Dev Biol. (2003) 47: 451-458.

Evidence that the testis determination pathway interacts with a non-dosage compensated, $X$-linked gene. P S Burgoyne, R Lovell-Badge and A Rattigan Int. J. Dev. Biol. (2001) 45: 509-512

The human SRY protein is present in fetal and adult Sertoli cells and germ cells. L Salas-Cortés, F Jaubert, S Barbaux, C Nessmann, M R Bono, M Fellous, K McElreavey and M Rosemblatt

Int. J. Dev. Biol. (1999) 43: 135-140

Transplantation of testis germinal cells into mouse seminiferous tubules. T Ogawa, J M Aréchaga, M R Avarbock and R L Brinster Int. J. Dev. Biol. (1997) 41: 111-122

Expression of a large number of novel testis-specific genes during spermatogenesis coincides with the functional reorganization of the male germ cell. C Höög

Int. J. Dev. Biol. (1995) 39: 719-726

The role of the mesonephros in cell differentiation and morphogenesis of the mouse fetal testis.

H Merchant-Larios, N Moreno-Mendoza and M Buehr

Int. J. Dev. Biol. (1993) 37: 407-415

Local control mechanisms in the testis.

K M Tähkä

Int. J. Dev. Biol. (1989) 33: 141-148

Endocrine function and regulation of the fetal and neonatal testis.

I Huhtaniemi

Int. J. Dev. Biol. (1989) 33: 117-123

5 yr ISI Impact Factor $(2008)=3.271$

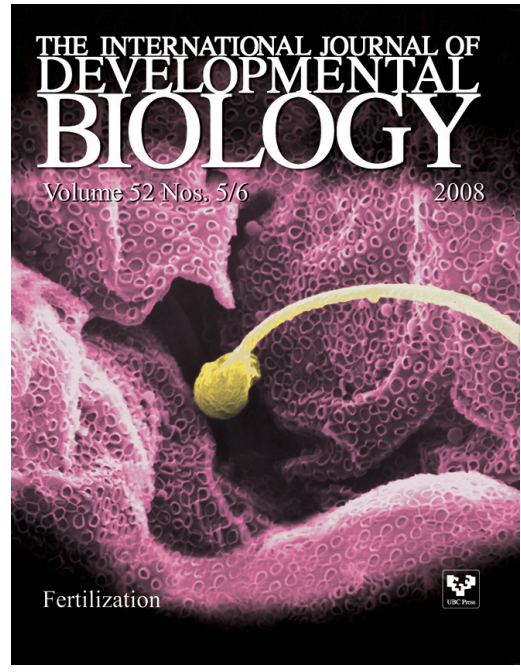

